\title{
Food Market and Cultural-led Urban Regeneration: An Experimental Project in Taipei City, Taiwan
}

\author{
P. N. Yin ${ }^{1}$ \\ ${ }^{1}$ Graduate School of Art Management and Cultural Policy, National Taiwan \\ University of Arts
}

\begin{abstract}
The article argues how a food market building in the old area of a city might work as a catalyst for a cultural-led urban regeneration. A food market stands more than 80 years not only supply food for neighbourhood, but also conveys much of community public memories. By making market a school/ community museum and retell the stories to children, the richness of local community histories turns into a positive energy to lead the urban regeneration matching the local needs, instead of sacrifice to developer's interest only.
\end{abstract}

\section{Introduction: Markets as Public Space}

Food markets are receiving much more attention worldwide, since they represent local food/agricultural and the cultural landscape in each area. Usually, it is the first thing one seems to experience one's daily life and local history. Traditionally speaking, food markets are locus as an exchange terrain for both the consumers and vendors for their economic function. Besides, they provide public services in urban planning systems, as well as a place for social interaction. In sum, food markets are public spaces in cities, that convey multiple significances for both the residents and tourists. Despite growing government interest in public space, however, there is a relatively limited amount of research on how public space is perceived and used. More specifically, the role of markets as public spaces has also been ignored. (Watson and Studdert, 2006: 2)

In the academic field, there is a considerable body of work that theories the public realm, from Habermas' notion of the public sphere as a site of rational debate and communication (Habermas, 1984) to Young's notion of the city as a space for 'the meeting of strangers' and as 'a community of difference' (Young, 1990). Other literature on the public realm has tended to focus on the decline of the public realm and privatization of social relations (Sennett, 1974) or on public spaces as sites of contestation or conflict. Such as Smith's work on gentrification (Smith, 1996) or the concept 'city trenches' by Kaznelson (1981). However, what is missing from these accounts are the day-to-day explorations and understandings of how different groups interact, or not, in public spaces. Yet, one of the key aspects of the contemporary city is the living of difference in the context of intense juxtaposition and social connection. It sets out to consider the everyday cultural practices that form much of the texture of daily urban life, especially focusing on markets. (Watson and Studdert, 2006: 2-3)

The food markets were under the control of the urban planning systems during Japanese occupation in Taiwan around the 1890s. That is to say, to review the establishment process of the food markets in Taiwan is not only a 
good chance to know more about the history and a city's daily life, and to conserve the food markets buildings is also an important issue of local heritage business. Nevertheless, it implies the close connection between the food markets conservation issues and the cultural-led urban regeneration policy. This is a key point the article intends to elaborate through the case study of the Hsin$\mathrm{Fu}$ food market, a registered historic building in Taipei City, reused as a cultural space in a dilapidated area, which has now become a hot spot for young people to recognize the old area of the city.

Nevertheless, as a matter of fact, it is not easy for the Taipei City government to manage a regeneration project and revitalize a cultural heritage in an old area. It was through a series of experimental projects organized and cooperated by some social groups and local communities to reclaim the identity by means of the stories behind the food selling and consuming experience in the food market. By means of reviewing one of the most important projects "Market as a Primary School", this article has tried to investigate as to how to revitalize a place through narrating touching stories.

\section{Food Markets in Cities: from vendors into urban service system}

\section{1. farmers market (Niu-Xu) in old times}

Literally speaking, the word "market" has both physical and symbolic meanings. It refers to a specific physical space where people get together for exchanges, and no matter what is exchanged, being goods, ideas, opinions, gossip, or fashion news, they create it in a public space. The prototype of a market in Greek times was agora. People will go there to meet others for conversation, and to exchange different ideas or goods. The publicness of the agora comes from its diversity, as it contains all types of varieties. To respect the varieties and differences constitutes a democratic society. The agora, forum, and the piazza, which are inclusive and friendly to people with different beliefs, religions, imply the spirit of democracy (Sennett, 1974).

However, the market in modern times has become a basic infrastructure and public service in urban daily life. It was not until the Japanese era that the urban system was set up around the 1890s in Taiwan, as a part of the colonial modernity project. Traditionally, there were so-called "Niu-xu" (cow market) in the old days, a periodical market for cow trades in certain public spaces. People gathered there to sell or buy poultry and livestock, and also their daily groceries, food, and so forth. It was the predecessor of today's food markets in Taiwan.
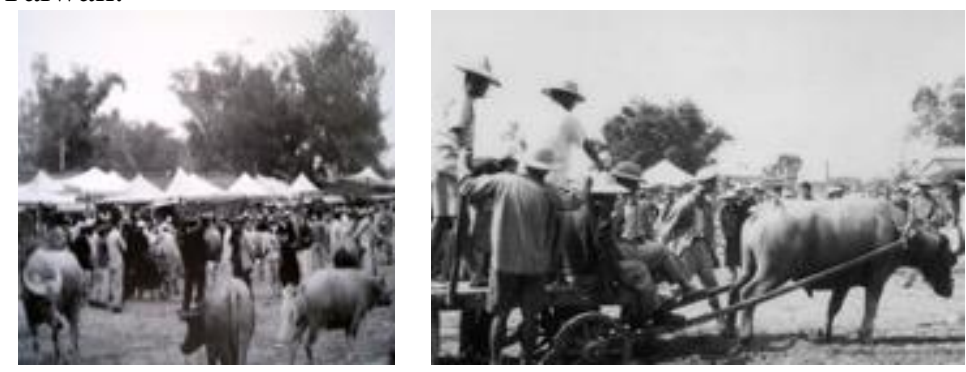

Fig. 1. 2. The old pictures of cow markets in Taiwan where people gather and shop. 
Little by little, the vendors converged on some important public spaces, where many people gathered, for example, the piazza in front of a temple. These vendors usually sold food, that included vegetables, meats, snacks and delicatessen. This kind of market transformed into the famous night markets in Taiwan's cities, for example, the night market in Keelung, and the Shi-Lin night market in Taipei. These markets famous for the delicious and traditional snacks and meals, and these food courts for local people were transformed into hotspots for tourists.

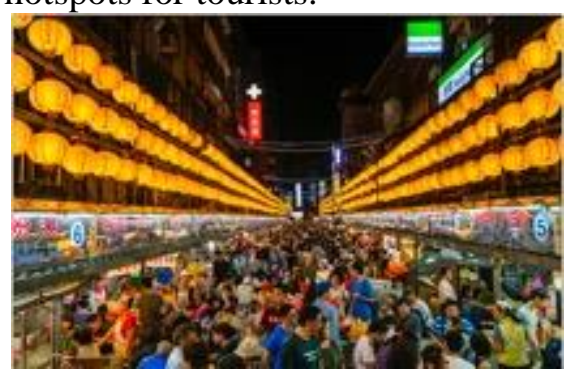

Fig. 3. Night market in Keelung, a famous site for gastronomic tourism

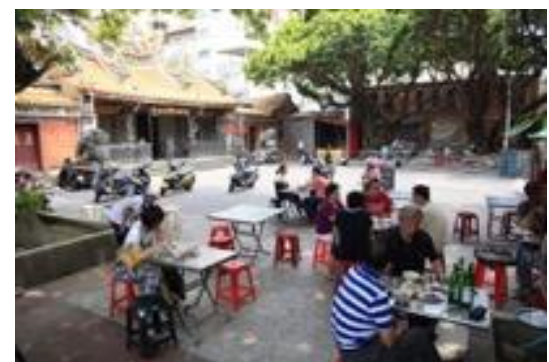

Fig. 4. A Famous food court in front of temple, in Taipei city.

\subsection{Urban service systems and the formatting of Hsin-fu food market}

However, the Japanese colonial government constructed the public market buildings under their urban planning system. In the beginning, the construction of the food market buildings was used for public health and tax collection. Besides, there were different kinds of market buildings for the Japanese and Taiwanese people. The former was usually composed of shopping malls and Shrines. The latter was mostly situated around the square in front of traditional temples. In general, the idea of market buildings comes from the Western urban planning method, which meant clean, rational, healthy, progressive, and modern, as the buildings' design took the Western/modern styles. That is, instead of building from wood or bricks, the modern market buildings were mainly built from steel and concrete.
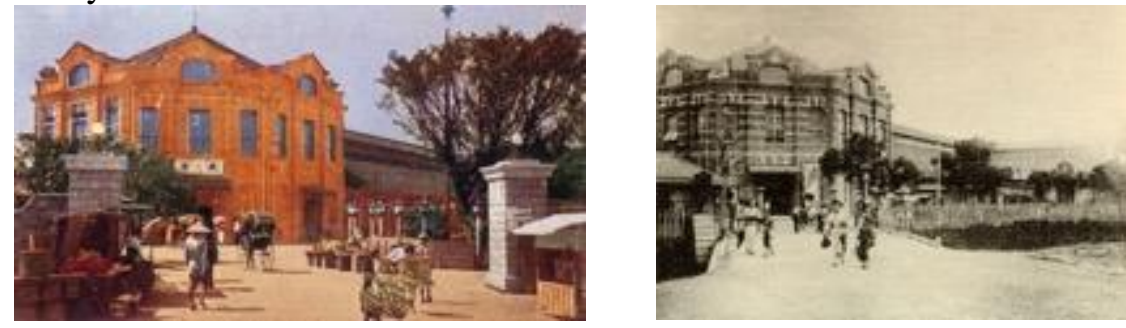

Fig. 5. 6. The market built on 1908, was one of the oldest in Taipei, now a registered monument. It was built for Japanese people, a fashion shopping mall then. It was then reused as a creative quarter in Taipei.

\subsection{How a food market become a cultural heritage}

Hsin-fu market was built in 1935. It was the first one to be built under the new regulation of public health by the Japanese Government at that time. Besides, it was built in a U-shape, which was the only one as a market in Taiwan. Accordingly, it was designed as a concern for the circulation, the ventilation, 
and the natural lighting. In 2006, it was registered as a municipal monument for its special building type, and also because it is still functioning well as a food market for over 80 years. However, from 2000 to 2010, the urban regeneration was on the table. The area where the Hsin-Fu market is located was one of the earliest developed which was facing the urgent issue of local revitalization. After a long conversation with the local community, the city government decided to turn the market into cultural facilities, which played as a catalyst for the local regeneration. The ideas came from the policy URS plan, proposed by the Taipei City Urban Regeneration Office. That is, not only to maintain the old market building in the same situation, but to take it as a catalyst to influence the surrounding areas.
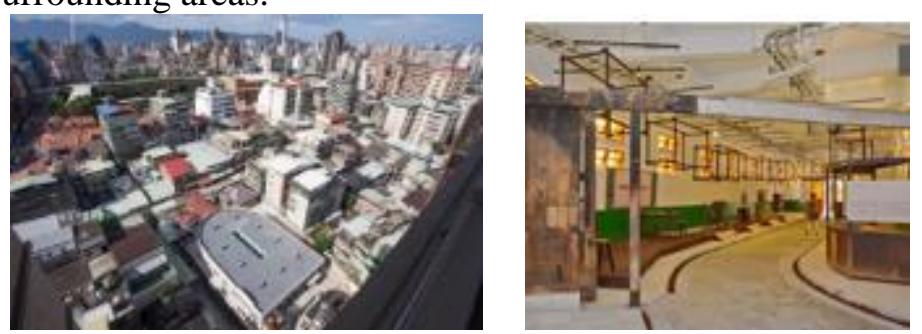

Fig. 7. 8. The appearance and interior of the Hsin-Fu market built in 1935

\section{Urban regeneration and food market: a social design approach}

\subsection{Urban Regeneration in Taipei city: A Brief History of URS Plan}

Since the 1980s, Taipei City has been facing urban expansion and sprawling issues. Taipei was developed along the Tamsui River, which was on the very western side of the city. Namely, the city was being expanded towards the eastern side. However, the old western areas were struggling with the hollowing out agendas. The revitalization of these old areas became the important campaign issues during the mayoral elections for over 20 years. During the mayors' terms, Mayors Ma and Hao, from 1998 till 2014, altogether 16 years, as to how to revitalize the old areas became one of the core issues in urban policies.

Nevertheless, to avoid the gentrification effects, the Taipei City Urban Regeneration Office proposed the "Urban Regeneration Station (URS)" plan. This implementation of the plan has unveiled the development mode of a cultural-led urban regeneration policy in Taipei City.

The URS, with its pronunciation rhyming with "yours", the Taipei Government made new efforts to attempt the urban regeneration by refocusing on the demolished historical memories. The government provided specific sites, and then encouraged and/or invited NGOs to take over. In the beginning, the government provided a short-term operational fee, as these NGOs proposed a variety of revitalizing space application through their innovation. These are not only the workplaces for the groups who are taking over, but also a nourishing place for the young creative workers. That is, by inviting these workers to stay and start a business in these old areas, people returned to the city's historic areas again. Then the business was expected to re-flourish.

These sites were mainly used for the URSs from two aspects. The first comes from the vacant historic buildings. The second were some empty houses 
which were donated to the city government. And the third, originally either public or temporary places provided for public usage, of which the city government guaranteed responsibility for the renovation and/or repairs. Strategically, the location of these sites is extremely vital, as they are usually located in the old areas of Taipei. Through the stationing of the creative workers, as they introduced their innovative ideas that would become a junction for the surrounding revitalization. Through the software operations, this strengthened the participation of the entire community and triggered the potential changes of the residents. On the other hand, these newly stationed industries prompted regional revitalization. In other words, this is distinct from traditional urban renewal, which often injects estate capital, removes the old, and builds a considerable number of new skyscrapers. Not only does this impact on the surrounding landscape, but the newcomers also change the structure of the buildings, and the core characteristics of the local community. This type of predatory urban renewal often means the destruction of the original community's routine.

From 2010, the URS plan began, and gradually 10 sites started their operations. The very first one, URS 127, was operated by the Department of Architecture at Tamkang University in May 2010. With its theme of urban aesthetics, speeches and lectures were held, as well as curating exhibitions of different artists and/or student's work. The mission of URS 127 was quite clear and simple. Namely, by curating interesting activities so as to invite local residents to enter the sites, and to know more of what the idea is of the URS. In addition, as the community participated in the revitalization of this district, they were familiarized with the idea of the URS policy regarding urban regeneration.
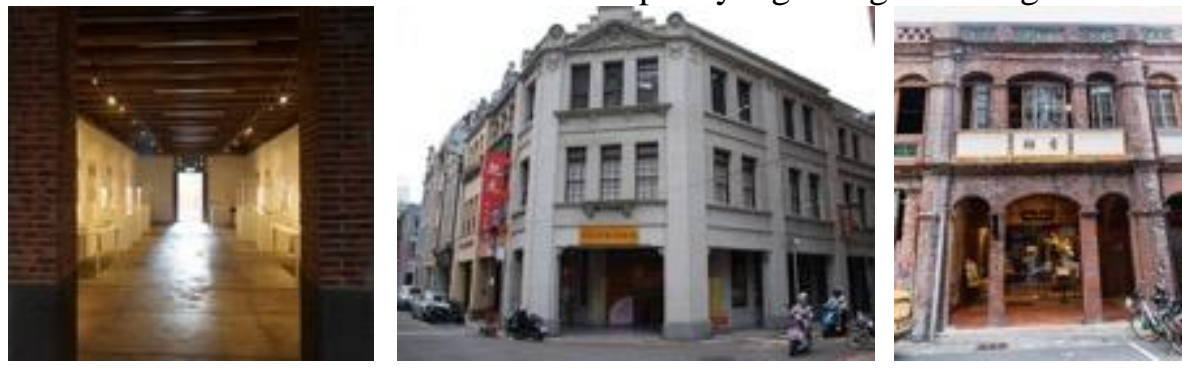

Fig. 9.10.11. URS 127, URS44 and URS 329 in Taipei City

Tamkang University ended its phasic role in October 2013. The site was then taken over by cultural and creative workers. During this period, the Taipei Government continually added sites such as URS 44, URS 155, URS 27W, etc. Activities were constantly arranged and held, attracting crowds to visit this old district, while boosting the surrounding commercial activities. A lot of young creative workers loved the historic atmosphere and the architectural characteristics, and therefore decided to open their stores or workshops around the old areas. As the creative design products were added, it attracted the younger consumers to visit the area, and this has led to the commercial regeneration of the old street. The spatial regeneration effect attracted URS 329, which is a privately-owned historic building located in an old area, that actively asked to participate in this plan.

From the public sector viewpoint, the URS have effectively fortified the district revitalization. However, an aesthetic economy and a symbolic consuming effect are the internal factors so that these plans can succeed. Entrepreneurship production methods, a highly developed society, increasing consumer capability, and leisure time, as well as an aesthetic trend in lifestyles, 
has caused a tight bond between daily purchases and individual subject identity. Scholars connected the transition from production to consumption patterns in the post-industrial society to reflexive modernity, and suggested the idea of aesthetic reflexivity (Lash and Urry, 1994).

Consumer Capitalism enabled the appearance of an abundance of material object aestheticization in terms of merchandise production, circulation, and consumption. In terms of sign and sense, these product services and content creates a tight bond among personal pleasure, emotion, or leisure, and the experience identification of the consumer. Urban economy, cultural production and spatial sign have created an "Economy of signs and space", referring to the contemporary fluid structure of globalization, which is the merging of the spatial sign economy. In the spatial sign system, its reflexivity of criticism and cultural permeation has facilitated the expansion of critical flexibility. Social agents are constantly released from their monitoring of heteronomy or social structure. Parallel to this phenomenon is the expansion of aestheticization. The main idea of reflexivity is that "aesthetic reflexivity" is beneficial for the conferring on self-interpretation and social background realization while searching for self-identification. Through sign consumption and aestheticism in daily life, the subject attempts to reconstruct the connection between self and social realization.

Simply stated, the food market is not only a site for daily purchase of food supplies, through the consumption and social interaction experience in the market, it represents the local history and aesthetics under the globalization context (Zukin, Kasinitz and Chen, 2016). By means of daily consumption, people might acquire much more local identification. To set up the old market building as a regeneration station, just as the aforementioned URS plan, as this might well work as a catalyst for local revitalization. That is why the food market, as a registered building, was to be transformed as a cultural space and anticipated as a frontier for local urban regeneration. It is an approach of cultural-led urban regeneration.

However, why a food market was no more functioned for its urban service? How people in neighbourhood shop for their daily needs? How about the job opportunities for those working inside the market? Is it a good policy for a food market to be transformed into a cultural space? Actually, the regeneration needs for certain places or regions involves two basic dimensions. The first is about its physical environment issue, for old areas might have some derelict space in need of being modified, or to re-evaluate its infrastructures and urban service. The second is about the symbolic value, namely, the identifiability and symbolic meaning of certain places have influenced how people read, feel, or interpreting it.

On the symbolic level, the area of the Hsin-Fu food market is one of the earliest developed regions in Taipei. There are many old industries, social networks, traditional religions, and folk beliefs. For instance, the area is famous for the splendid Lon-San Temple, and traditional delicious food, however, it is also agglomerated a lot of homeless people and sex workers, and is also famous for its stolen goods markets. That is, the oldest and earliest developed areas were also a synonym of the underdeveloped region from the whole city's viewpoint. How to change the negative image of this area and the stigmatization of the old neighbourhood, however, on the symbolic level, is a critical issue, and may be the most vital one in urban regeneration.

On the physical environment level, the shortage of good urban service is one of the main problems in the old areas in Taipei. Lacking open spaces, 
community parks, overcrowded housing, shortage of car-parking space, and so forth. That is, to lower down the density of these old areas might help quite a lot as the first step.

In sum, on the policy thinking level, to revitalize certain places would not only be to tear down or rebuild new buildings, as a design for the real needs of the local residents would be the very first step, a core idea of social design. Meanwhile, to encourage local people to re-evaluate their daily life, their local histories for their own families, and the development process of the city, thereby allowing others to better understand the local life story in order to change the stigmatization is another necessary strategy. Under this kind of proposition, food markets, a place full of social interaction of local people, a long history of consumption and exchange invited people to share their experience and memories, which made it an advantageous site for the culturalled urban regeneration of Taipei.

\subsection{The practice of "Market as a Primary School" project}

The concept of the project, "market as a primary school", comes from a professional activist group called the "Urban Yeast", organized by a few young creative workers. They proposed a project named "Plan Global" in 2006. In their opinion, creative workers should propose different creative actions/projects to make one's city more attractive, and liveable, as one would enjoy staying in a charming city. Urban yeast implies the fermentation effect what these talented people have aroused in cities that one belongs to. Impressed by their ideas and cultural actions, they were invited to propose a project about how to revitalize the old food market that was no longer a place to sell food in 2016.

According to the project which the Urban Yeast team proposed, they argued that the more one knows about a certain place, the more one might like it. The formula is more effective to teach children to learn more about their own neighbourhood. Based on these propositions, they planned and practiced the "Market as a primary school", that is, to invite primary school students to be in the food market, to learn inside it, and the venders to act as tutors for the children, with different vendors' stalls and booths to become classrooms.

The project was interesting and creative, yet, it was far more difficult to put into practice. First of all, they have to invite the market vendors to participate in the project, and to be tutors for the children. In the beginning, the market's trade association didn't accept their invitation. They spent more than three months persuading them. They didn't agree because of two reasons. Firstly, they think of themselves are vendors, which means they are not well-educated enough to be teachers. The second reason is they can't understand why the Urban Yeast team proposed this project, and what was their intention? Through many meetings and discussions, they finally changed their mind. The most important reason to alter their thoughts was that they all agreed that the neighbourhood was getting old, both the people and the physical environment, as they hoped the younger generation would learn more about their own history, by way of the stories that had happened there. In addition, they also know that the younger generation would not visit or buy food there just because of knowing so little about the market, both the history, and their little knowledge about the food on their dinner table.

After the operational team had the chance to cooperate with the trade association, they brain-stormed the original project together, and did some 
modifications to the idea proposed by the trade association according to the real situation in situ.

However, this was only the first step. The next challenge was who would be the guests to learn inside the market? They invited the primary schools in the neighbourhood, only to be refused. The reason given was that most of the schools' principals didn't recognize the project as any part of the school curriculum. Similarly, the team visited some teachers, and invited those who might be interested in the project, and to develop their plans together in order to match the teaching goals of each course. Fortunately, they finally found three primary school teachers nearby, with three classes and different courses.

They held four workshops, one for families and the other three for the school children organized by the teachers they had invited. The first workshop lasted a week. It was signed up by the parents with their children as visitors and organized as a campaign named "parent-child food market week". Visitors were guided by the vendors to learn more about the rich local history, to interview some vendors themselves, and to talk with the vendors to share their shopping experience in the market. Besides, the workshop not only invited the visitors to learn about the market, they also had to participate in discussions on how to modify or redesign the market in a better way, both according to the ideas from the consumer and seller's needs and thoughts.
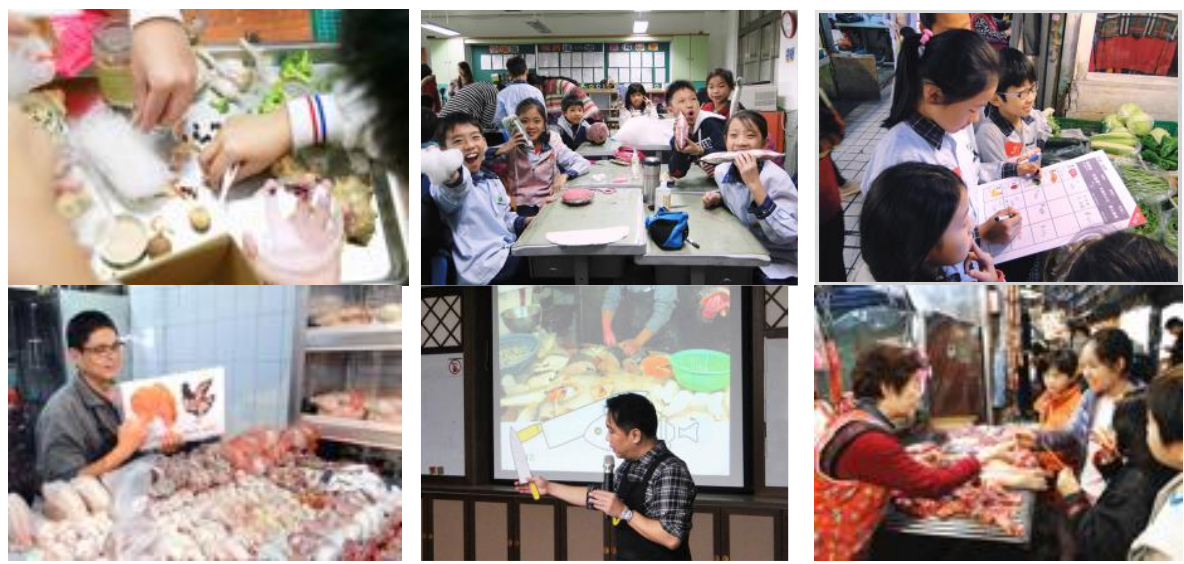

Fig. 12.-17. Pictures of the workshops of the "Market as primary school" project

The other three workshops for the school children and their teacher was to visit the market arranged by the three main topics, entitled "the food ingredient class in market", "the food exploration class in market" and "the cutlery class in market". In order to maximize the learning effect, the project team and teachers did a lot of preparation in advance. For example, children were taught the English names of the food during their English course in school. Moreover, they learned some basic nutrition concepts from the different types of food, and they had to learn how to calculate the calories of different food in the Math class, or to design recipes of their choice. Some booths in the market were decorated like a classroom, with posters on the walls to demonstrate information about the food, including being written in English. Some stalls arranged with scales for students to practice how to find the exact food to match their recipe, and learn how to buy it in the right weight, and so forth. Of course, they invited some vendors to introduce their special cuisines and ingredients. For example, one stall introduced the tempura which was hand made from grinding the flesh of fish, and had been for over 50 years. An old lady was 
invited to introduce the dishcloth, tablecloth, and other products, for she had served in the shop for over 30 years.

Meanwhile, at the cutlery class workshop, they invited different shopkeepers to teach the children what are the characteristics of using a knife for each type of food, the one for chopping pork, the one for poultry, the one for stripping fish scales, and so forth. By the means of a demonstration, they also showed more details and the difference of each kind of meat to the students, through an anatomic way.

Furthermore, they also did some rearrangement of the physical side in the market, which might be called social design. They invited IKEA, the furniture corporation, to provide a public relations plan, which had two parts on different scales. First, they did some visual design in the market, for example, the shop sign board, the format of the stalls, and the colour scheme of the interior space of the market, and even the font design for the market as a whole. Secondly, on a voluntary basis, some vendors that were not satisfied with their stalls, so they invited the IKEA team to hear their needs and ideas, and to rearrange the stalls for them for free, nevertheless, these improvement stories would become IKEA's credits, the so-called Corporate Social Responsibility (CSR). One of these improvements was a vegetable stall that had lasted for three generations, and the elderly lady was over 80 years old, with her sons and grandchildren to sell vegetable in the market for over 60 years. After the redesign project was completed, the IKEA team also taught the vendor how to change their display of vegetables, by the different ways to pairing them, for example, to put them in layers, different colours in different rows, to make the shop like a colourful picture, and more attractive to buyers. However, the most important change was, to use certain appropriate furniture to improve the 85-year-old lady's back pain. Besides, she enjoyed rearranging these vegetables every day, which might never have happened in her mind, since they used to sell them in the traditional way, without caring about the amenities and pleasure for both the consumers or venders in the traditional food markets in Taiwan.

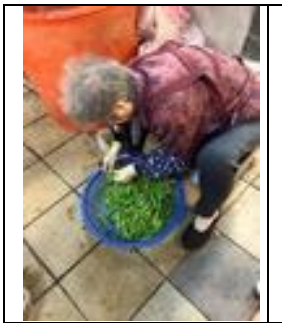

Fig. 18.19. the 85 years old lady working in the market as vegetable vendor

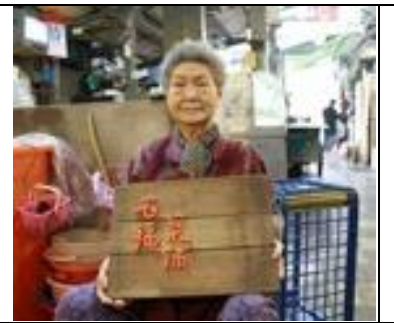

Fig. 20. the original stall and its simulation picture for its restoration

Although the project was held only once, however, according to the Urban Yeast team, people asked to have more workshops. The team still pays attention to the food markets issues in Taiwan, and sincerely hope that they will have the chance to introduce more stories to the visitors. After all, to let people know much more about a place would naturally make them care more about it, nevertheless, this is about food on the dinner table, the food supply between the countryside and the city, the biodiversity and the cultural diversities of local history observed through the food markets, and the participatory social design for the local community. A food market always has many more stories than people to tell, and it is might well be the starting point for people try to find ways to develop any cultural-led regeneration projects. 

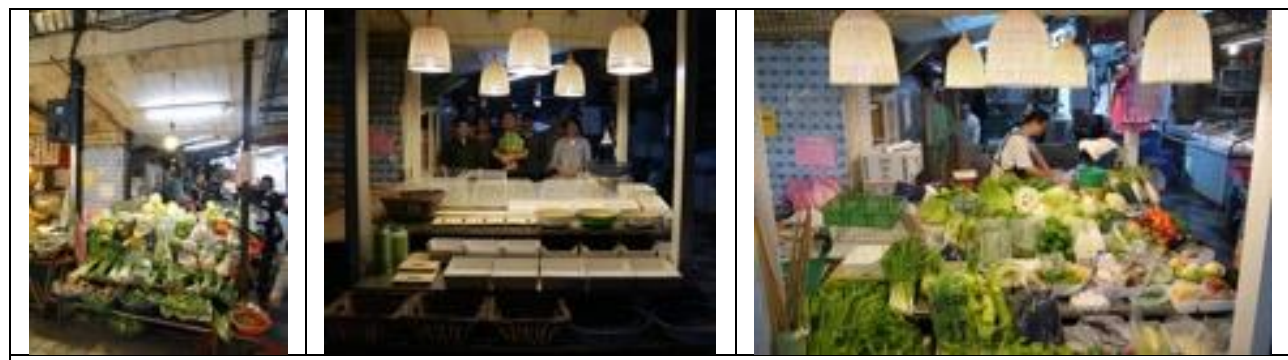

Fig. 21. 22.23. the photos before and after of the vegetable stall restoration

\section{Discussion and Conclusion}

After describing the stories about the "Market as a Primary School" project that happened in the Hsin-Fu food market, there are some points to make regarding the relationship between the food markets and the cultural-urban regeneration issues.

1. To investigate the history of the food market, not only to accumulate the historic material about local development, but also to revisit the collective memory of the community.

That is to say, instead of urban renewal to uproot the local community without caring about their attachment to the place. However, the cultural-led urban regeneration approach usually pays much more attention to digging deeper into the collective memory, and through solid field research, to find some useful strategy for local regeneration.

2. Curating knowledge around food to reconstruct the information and the significance of the system of daily life practices.

Food markets are part of one's daily life, yet, one takes them for granted since they have functioned as part of the urban public service for a long time. However, taking the food story in our daily life as a main theme to curate projects for life aesthetics is turning it upside down, to re-narrate the significance of daily life practice as a cultural resistance terrain.

3. To invite the vendors in the market to share their daily experiences which could become the resources for aesthetics and a real-life education of children.

Since the stories shared from the market look like triviality of the local community, however, the daily life practice has become a contested terrain, as the nutrition of everyday life practice might well be the critical base for a cultural-led regeneration.

4. To empower the vendors to re-interpret the food and retailing culture in the food market of a local community.

People who have a business or work in food markets were usually assumed as being from the lower class of society in Taiwan, that is, their experience and viewpoint were thought to be unimportant. However, sustainability comes from cultural diversity. To empower the local community should not only sustain the cultural diversity, but 
also be helpful to a cultural-led urban regeneration approach, in an urban conservationist way.

5. To propose a vision of the social design approach rather than a physical improvement of the market building.

The Hsin-Fu market building has been standing for more than 80 years. The physical environment, indeed, needed some restoration work. However, by inviting vendors to renovate their shops together with designers, to listen to their needs and thoughts, not only to beautify the exterior, but also to care about the users' practical needs to help people to improve their daily work conditions.

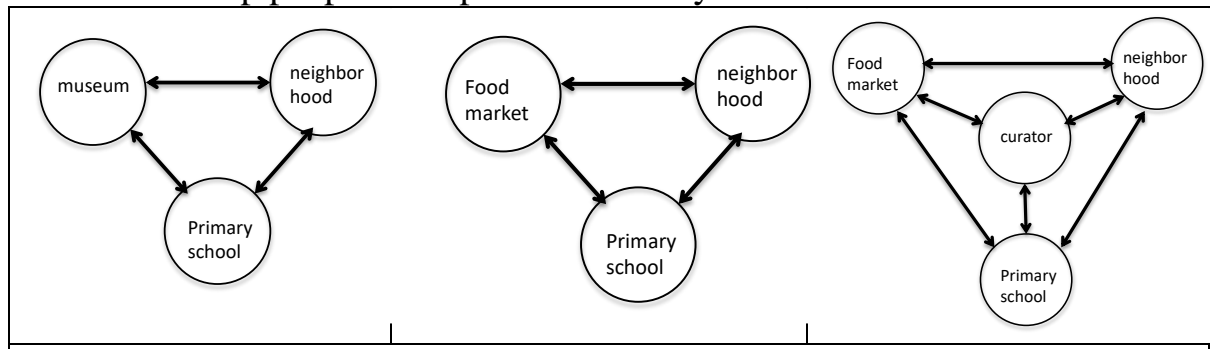

Fig. 24. 25.26. the concept diagram of triad relationship between the primary schools, the community museum and the neighbourhood

Through the discussion above, some interesting figures might be drawn from the food market and the local neighbourhood. The food market is just like a local museum to serve the people in their neighbourhood, as they both are public services in certain ways. However, unlike curators working in a museum to provide educational programs and activities for school children, food markets share their daily life through experience economy. That is to say, if there are some curators working with people in the market, as per the program practiced by the Urban Yeast team, the food market can play a key role in the neighbourhood community, so as to provide educational programs for children in the schools. Further, as aforementioned, a market not only sells food, it also functions as a place for economic exchange, as it combines the economic and cultural function at the same time, on both the urban economic and cultural policy levels, especially when the market is an historic building, as it might turn into the nexus for a cultural-led regeneration process.

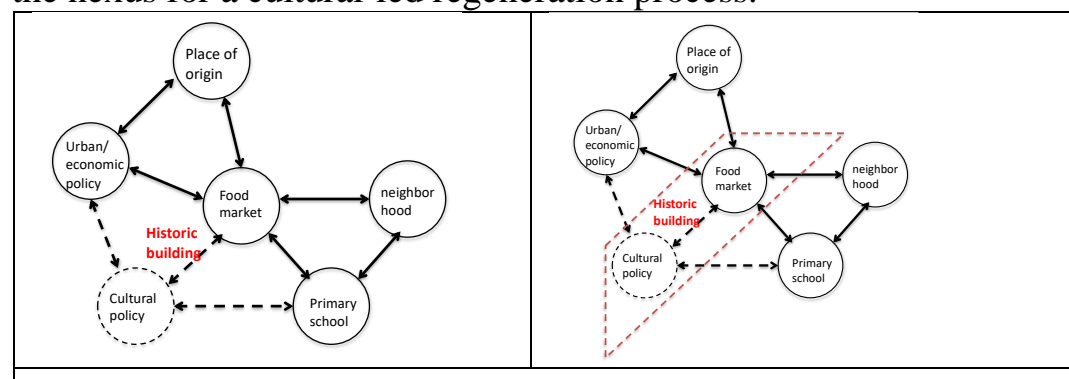

Fig. 27. 28. Taking food market as the nexus, whcih combines the economic and social connection between the market, the primary schools, and the neighbourhood from the economic to the cultural policy

This article started from a very simple question, namely, how the URS project functions in an 80-year-old historic building of food market, and how to develop a cultural-led regeneration plan? This plan should not only involve the local community so as to improve their physical environment, but also help 
to empower the vendors, and to reinterpret the local history to sustain the areas cultural diversity in the city.

In sum, I would like to depict a diagram as below. Taking the food market as a starting point, it functions for economic exchanges, social interactions, and food supply, as it consists of the industrial policy in the city. Meanwhile, it is also a cultural heritage in the city, with its rich tangible and intangible attributes. It plays an important role in cultural policy. And thirdly, food culture might well become the base for gastronomic tourism and a cultural tourism policy. So, maybe, it is possible to organize all these three into a framework of creative cultural industries in the cities, which positively leads towards a cultural-led regeneration approach.

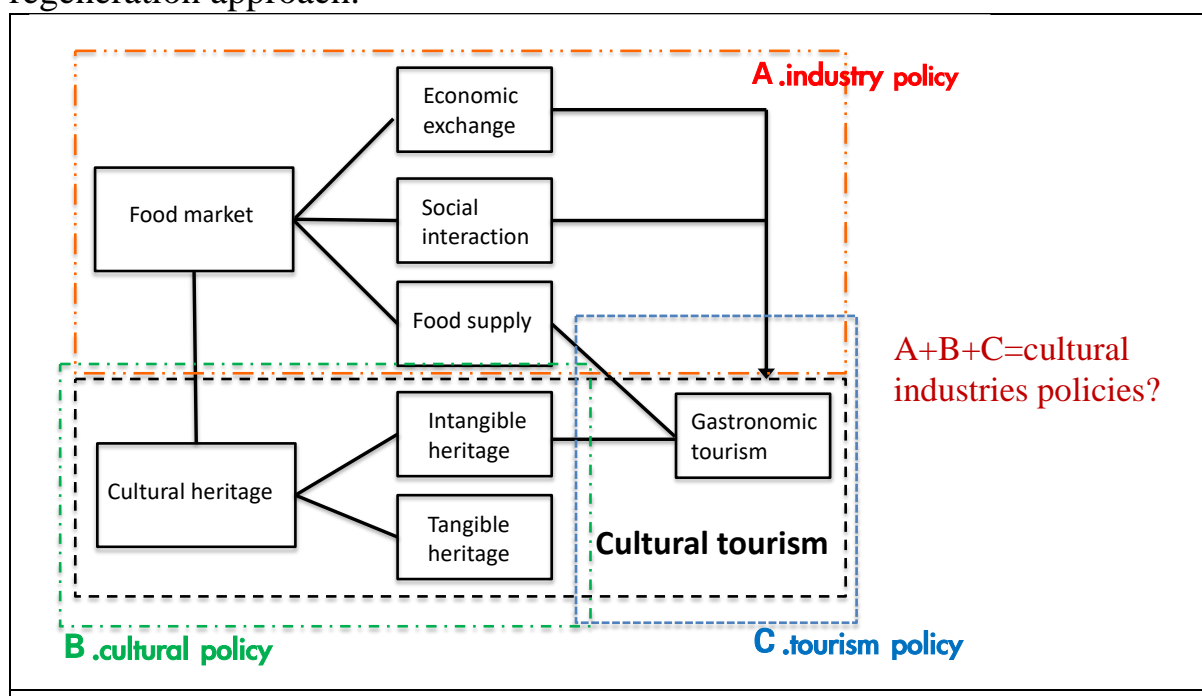

Fig. 29. Taking food market as the nexus, a concept diagram combines the economic, cultural heritage and tourism policy, which might lead to a cultural-led urban regeneration imagination.

\section{References}

1. Habermas, J. The theory of communicative action vol.1: reason and the rationalisation of society, London: Heinemann, 1984.

2. Kaznelson, I. City trenches: urban politics and pattering of class in the US. New York, NY: Pantheon Books, 1981.

3. Lash S. and Urry, J. Economies of Signs and Space, London: Sage, 1994.

4. Sennett, R. The fall of the public man, New York, NY: Norton, 1974.

5. Smith, N. The new urban frontier: gentrification and revanchist city, London: Routledge, 1996.

6. Watson, W. and Studdert, D. Markets as sites for social interaction: space of diversity, Bristol: The Polity Press, 2006.

7. Young, I. Justice and the politics of difference, Princeton, NJ: Princeton University Press, 1990.

8. Zukin, S., Kasinitz, P. and Chen, X. Global cities, local streets: everyday diversity from New York to Shanghai, London: Routledge, 2016. 